\title{
Manajemen Bank Sampah: Menjadikan Sampah Bernilai Ekonomi Bagi Masyarakat Pondok Pesantren
}

\author{
Globila Nurika ${ }^{1}$, Dewa Ngakan Gde Wahyu Mahatma Putra², Niajeng Novta Dwi Nafisah ${ }^{3}$, \\ Rifdul Basied ${ }^{4}$ \\ 1,2,3,4 Kesehatan Masyarakat, Fakultas Kesehatan Masyarakat, Universitas Jember, Jember, Indonesia \\ Email: ${ }^{1}$ nurikaglobila@unej.ac.id, ${ }^{2}$ dewawahyu@ unej.ac.id, ${ }^{3}$ novtaniajeng@gmail.com, \\ ${ }^{4}$ rifbas8@gmail.com
}

\begin{abstract}
Abstrak
The Nurul Jadid Islamic Boarding School has a problem with the generation of plastic cup waste from drinks. So far, the waste is only collected and burned. The land/building resources for the waste bank and the existing human resources are sufficient to carry out waste bank activities. However, this condition is not supported by sufficient knowledge and skills in implementing waste management activities through waste banks. Therefore, it is necessary to have community service activities in the form of education, training, and assistance to the managers of Islamic boarding schools and the community in the environment around Islamic boarding schools to carry out waste management activities with a waste bank system. This community service activity is carried out in 3 stages, namely situation analysis partner conditions, implementation of interventions, and evaluation activities. Educational activities showed an increase in participants' knowledge about waste management with the waste bank system by 10,938 points. The training activities showed an increase in the ability of participants to carry out waste bank management activities. Assistance activities for the establishment of a waste bank system which show that the managers of Islamic boarding schools have been able to develop a waste bank organizational system and waste bank management flow. It can be concluded that this community service activity is a very strategic effort in order to prepare participants to carry out activities in waste management starting from the source and making waste have economic value.
\end{abstract}

Keywords: Waste Bank, Islamic Boarding School, Garbage, Waste Sorting, Waste Management

\begin{abstract}
Abstrak
Pondok Pesantren Nurul Jadid memiliki permasalahan timbulan sampah gelas plastik bekas minuman. Selama ini, sampah tersebut hanya dikumpulkan dan dibakar. Sumber daya lahan/bangunan untuk tempat bank sampah dan jumlah sumber daya manusia yang ada telah mencukupi untuk dilaksanakan kegiatan bank sampah. Namun kondisi tersebut tidak didukung dengan adanya pengetahuan dan keterampilan yang cukup dalam pelaksanaan kegiatan pengelolaan sampah melalui bank sampah. Oleh karena itu, perlu adanya kegiatan pengabdian kepada masyarakat yang berbentuk edukasi, pelatihan, dan pendampingan kepada pengelola Pondok Pesantren dan masyarakat di lingkungan sekitar Pondok Pesantren untuk melakukan kegiatan pengelolaan sampah dengan sistem bank sampah Kegiatan pengabdian kepada masyarakat ini dilakukan dengan 3 tahap yaitu analisis situasi kondisi mitra, pelaksanaan intervensi, dan kegiatan evaluasi. Kegiatan edukasi menunjukkan peningkatan pengetahuan peserta tentang pengelolaan sampah dengan sistem bank sampah sebesar 10,938 poin. Kegiatan pelatihan menunjukkan peningkatan kemampuan peserta dalam melakukan kegiatan manajemen bank sampah. Kegiatan pendampingan pembentukan sistem bank sampah yang menunjukkan bahwa pengelola Pondok Pesantren telah mampu menyusun sistem organisasi bank sampah dan alur manajemen bank sampah. Dapat dismpulkan bahwa kegiatan pengabdian kepada masyarakat ini merupakan suatu upaya yang sangat strategis dalam rangka menyiapkan peserta untuk beraktivitas melakukan pengelolaan sampah mulai dari sumbernya dan membuat sampah memiliki nilai ekonomi.
\end{abstract}

Kata Kunci: Bank Sampah, Pondok Pesantren, Sampah, Pemilahan Sampah, Pengelolaan Sampah

\section{A. PENDAhULUAN}

Sampah merupakan hasil dari aktivitas manusia yang berbentuk padat dan apabila tidak dikelola dengan baik maka akan meningkat pencemaran lingkungan. Berdasarkan data global, lembaga keuangan 
internasional, menyebutkan bahwa terdapat 2,01 miliar ton sampah menupuk di dunia pada tahun 2016 dan terus bertambah jumlah setiap tahun. (Setiawan, 2021) Di Indonesia, angka timbulan sampah juga mengalami peningkatan setiap tahunnya. Pada tahun 2019, timbulan sampah di Indonesia mencapai 34.584.584.16 ton/tahun dengan hanya sebesar 43,93\% upaya penanganan yang telah dilakukan atau setara dengan 15.191.504.74 ton/tahun. (SIPSN, 2020) Selain itu, data Survei Kesadaran Manajemen Sampah Waste4Change 2019 menunjukkan bahwa sebanyak 50\% rumah tangga di Indonesia masih belum melakukan pemilahan sampah sebagai bentuk pengurangan timbulan sampah di lingkungan. (Kompas, 2020) Berdasarkan angka tersebut, perlu adanya upaya penanggulangan sampah secara berkelanjutan mulai dari sumbernya. Sumber sampah dapat berasal dari rumah tangga, perkantoran, industri, Institusi, pariwisata dan tempat lainnya. Pengelolaan sampah dapat dilakukan melalui upaya 3R (Reduce, Reuse, dan Recycle). Upaya tersebut harus dilakukan secara massif untuk menurunkan angka timbulan sampah di lingkungan. Dalam mendukung upaya implementasi 3R di masyarakat, bank sampah menjadi salah satu program yang dapat diterapkan dan memiliki potensi peningkatan pendapatan bagi masyarakat yang menjalankan program tersebut. Program bank sampah selama ini mampu memberikan tambahan nilai ekonomi bagi sampah yang dihasilkan di masyarakat, khusuusnya sampah berjenis anorganik seperti botol kaca, botol plastik, dan lain sebagainya. Oleh karena itu, sebagai solusi pengelolaan timbulan sampah di lingkungan, maka bank sampah dapat dikenalkan dan diterapkan oleh masyarakat dari berbagai kalangan.

Pondok pesantren merupakan salah satu lembaga pendidikan di Indonesia yang merupakan wadah santri untuk melakukan kegiatan belajar ilmu pengetahuan agama. Sebagai lembaga pendidikan, maka pesantren juga berkewajiban penuh dalam ikut serta membersihkan lingkungan, dengan banyaknya sampah yang berada di sekitar kita terutama di lingkungan pesantren. Seiring dengan bertambahnya aktivitas pesantren yang terus meningkat, maka sampah yang dihasilkan pun juga semakin bertambah. Di antara timbunan sampah, terdapat sampah berbahan plastik yang mendominasi sepert botol atau gelas bekas air mineral. Pondok pesantren saat ini sudah seharusnya menjadi tempat untuk belajar tentang pengelolaan sampah yang benar, memulai membangun kesadaran akan penanganan dan pengelolaan sampah dengan membentuk bank sampah berbasis pesantren (Ibrahim, 2016). Seperti amanat pada Peraturan Pemerintah Republik Indonesia Nomor 81 Tahun 2012 Tentang Pengelolaan Sampah Rumah Tangga dan Sampah Sejenis Sampah Rumah Tangga, masyarakat memilki peran yang besar dalam upaya pengelolaan sampah yang dihasilkan termasuk bagi masyarakat di lingkungan pondok pesantren.

Pondok Pesantren Nurul Jadid di wilayah Kabupaten Situbondo memiliki permasalahan terkait pengelolaan sampah terutama sampah gelas plastik bekas minuman para santri yang jumlahnya akan terus meningkat saat ada kegiatan keagamaan yang diselenggarakan. Selama ini, sampah tersebut hanya dikumpulkan dan dibakar. Pengelola Pondok Pesantren dan masyarakat sekitar menganggap bahwa sampah adalah barang yang sudah tidak layak pakai dan seharusnya segera dimusnahkan. Namun, hal ini bukan menjadi solusi untuk meminimalkan timbulan sampah di lingkungan. Akan tetapi akan menambah pencemaran udara di atmosfer. Berdasarkan hasil analisis situasi dengan kunjungan lapangan, wawancara, dan pengamatan terhadap lingkungan Pondok Pesantren Nurul Jadid, dapat diidentifikasi beberapa permasalah prioritas yang dihadapi yaitu belum adanya sistem pemilahan sampah dari sumber dan kurangnya pengetahuan serta keterampilan pengelola Pondok Pesantren dan masyarakat di lingkungan sekitar Pondok Pesantren mengenai cara pengelolaan sampah dengan menerapkan bank sampah. Sumber daya lahan/bangunan untuk tempat bank sampah dan jumlah sumberdaya manusia yang ada di Pondok Pesantren Nurul Jadid mencukupi untuk dilaksanakan kegiatan bank sampah setiap hari. Namun kondisi tersebut tidak didukung dengan adanya pengetahuan dan keterampilan yang cukup dalam pelaksanaan kegiatan pengelolaan sampah melalui bank sampah. Oleh karena itu, perlu adanya kegiatan pengabdian kepada masyarakat yang berbentuk edukasi, pelatihan, dan pendampingan kepada pengelola Pondok Pesantren dan masyarakat di lingkungan sekitar Pondok Pesantren untuk melakukan kegiatan pengelolaan sampah yang dapat meningkatkan nilai ekonomi sampah melalui bank sampah. Sehingga kegiatan pengabdian kepada masyarakat yang dilakukan akan menghasilkan luaran sebagai berikut: (1) peningkatan pengetahuan dan keterampilan pengelola Pondok Pesantren dan masyarakat di lingkungan sekitar Pondok Pesantren mengenai cara pengelolaan sampah dengan menerapkan bank sampah, dan (2) terbentuknya sistem bank sampah di Pondok Pesantren Nurul Jadid.

\section{B. PELAKSAAN DAN METODE}

Kegiatan pengabdian kepada masyarakat ini dilakukan dengan 3 tahap yaitu analisis situasi kondisi mitra, pelaksanaan intervensi, dan kegiatan evaluasi. Kegiatan analisis situasi kondisi mitra (Pondok Pesantren Nurul Jadid) dilakukan pada tanggal 30 Agustus 2020 dengan cara kunjungan lapangan, wawancara, dan pengamatan untuk menggali prioritas masalah yang dihadapi dalam pengelolaan sampah. Pelaksanaan intervensi dilakukan pada 27 September 2020 sebagai solusi atas permasalah pengolahan 
sampah yang dihadapi. Kegiatan intervensi ini dilakukan dengan cara edukasi pengelolaan sampah dengan sistem bank sampah, pelatihan penerapan sistem bank sampah, serta pendampingan pembentukan sistem bank sampah di lingkungan Pondok Pesantren Nurul Jadid. Kegiatan intervensi ini dimulai pukul 09.00 WIB sampai pukul 11.00 WIB. Sasaran dari kegiatan intervensi ini adalah perwakilan santri Pondok Pesantren, pengurus Pondok Pesantren, dan perwakilan masyarakat di sekitar Pondok Pesantren Nurul Jadid dengan total sebanyak 35 orang. Jumlah dan durasi waktu kegiatan intervensi ditetapkan berdasarkan perhitungan 50\% kapasitas ruangan yaitu 70 orang serta jumlah materi yang akan disampaikan karena kegiatan ini dilakukan selama masa pandemi covid-19, sehingga protokol kesehatan tetap dapat dijalankan selama kegiatan berlangsung. Selain itu, selama kegiatan berlangsung, seluruh peserta dan tim pelaksana yang berjumlah 4 orang menggunakan masker untuk mencegah penularan Covid-19.

Kegiatan edukasi tentang pengelolaan sampah dengan sistem bank sampah yang meliputi: (1) konsep pengelolaan sampah domestik, dan (2) manajemen bank sampah dalam meningkatkan nilai ekonomi sampah domestik, dilakukan menggunakan media power point. Metode interaktif dipilih untuk kegiatan edukasi ini untuk meningkatkan partisipasi peserta dan agar materi yang disampaikan dapat dengan mudah dipahami. Kegiatan edukasi ini bertujuan untuk meningkatkan pengetahuan peserta tentang tentang pengelolaan sampah dengan sistem bank sampah. Peserta diberikan pre-test dan post-test untuk mengetahui peningkatan pengetahuan peserta. Selain itu, peserta dibekali dengan modul tentang "Konsep Pengelolaan Sampah Domestik" dan "Manajemen Bank Sampah" (Gambar 2) sebagai media pembelajaran lanjutan pasca kegiatan edukasi.

Setelah kegiatan edukasi selesai, selanjutnya dilakukan kegiatan pelatihan penerapan sistem bank sampah dilakukan dengan menggunakan media power point dan pemutaran video. Kegiatan ni bertujuan untuk memberikan gambaran secara nyata kepada peserta tenatang proses manajemen bank sampah yang nantinya akan diterapkan di Pondok Pesantren. Metode pelatihan yang digunakan adalah role play. Pelibatan peserta dalam kegiatan role play dilakukan bertujuan untuk memudahkan peserta dalam mengingat alur dan proses bank sampah yang dimulai dari pemilahan sampah, pendaftaran tabungan ke bank sampak, penimbangan, pencatatan, hingga penjualan ke pengepul sampah. Evaluasi kegiatan ini dilakukan dengan cara observasi untuk menilai peningkatan keterampilan peserta dalam melakukan proses manajemen bank sampah. Kegiatan terakhir yaitu pendampingan pembentukan sistem bank sampah. Kegiatan ini dilakukan terbatas dengan cara diskusi bersama pengelola Pondok Pesantren untuk membentuk susunan oranisasi dan alur manajemen bank sampah di Pondok Pesantren Nurul Jadid. Sebagai bentuk monitoring dan evaluasi kegiatan pengabdian kepada masyarakat ini, hasil pre-test dan post-test pada kegiatan edukasi selanjutnya dilakukan analisis statistik menggunakan uji paired-sample t-test untuk menghitung nilai signifikasi perbedaan pengetahuan peserta, serta melakukan kegiatan komunikasi dengan pihak pengelola Pondok Pesantren pasca kegiatan pengabdian masyarakat selesai untuk mengetahui implementasi bank sampah yang telah dibentuk.

\section{HASIL DAN PEMBAHASAN}

\section{Analisis Situasi Kondisi Mitra}

Kegiatan penggalian data lapang bentuk analisis situasi dan survei lokasi untuk pelaksanaan kegiatan pengabdian kepada masyarakat ini dilakukan pada tanggal 30 Agustus 2020. Kegiatan ini bertujuan untuk menggali prioritas permasalahan yang dihadapi oleh Pondok Pesantren Nurul Jadid dalam hal pengelolaan sampah serta merencakan pelaksanaan kegiatan pengabdian kepada masyarakat yang meliputi penentuan sasaran dan jumlah peserta, serta lokasi pelaksanaan kegiatan. Informasi dalam penggalian data lapang ini didapatkan dari pengelola Pondok Pesantren Nurul Jadid yaitu Hj. Nurul Qomariyah. Adapun data lapang yang didapatkan pada kegiatan ini adalah sebagai berikut:

1. Peserta yang akan diundang untuk mengikuti kegiatan pengabdian kepada masyarakat ini adalah perwakilan santri Pondok Pesantren, pengurus Pondok Pesantren, dan perwakilan masyarakat di sekitar Pondok Pesantren Nurul Jadid yang berjumlah sebanyak 35 orang. Pemilihan peserta tersebut diharapkan dapat mewakili masyarakat Pondok Pesantren yang nantinya akan melanjutkan mengedukasi masyarakat lainnya yang tidak menjadi peserta kegiatan pengabdian kepada masyarakat ini. Pembatas jumlah peserta dilakukan karena memperhatikan kapasitas ruangan agar tetap memenuhi protokol kesehatan selama masa pandemi covid-19.

2. Lokasi pelaksanaan kegiatan sosialisasi dan pelatihan ini akan dilaksanakan di rumah Hj. Nurul Qomariyah, yang sekaligus akan dijadikan lokasi Bank Sampah dan kantor manajemen Bank Sampah Pondok Pesantren Nurul Jadid. 
3. Hasil kegiatan analisis situasi ini menghasilkan permasalahan utama yang dihadapi oleh Pondok Pesantren Nurul Jadid dalam pengelolaan sampah yaitu belum adanya sistem pemilahan sampah dari sumber dan kurangnya pengetahuan serta keterampilan pengelola Pondok Pesantren dan masyarakat di lingkungan sekitar Pondok Pesantren mengenai cara pengelolaan sampah dengan menerapkan bank sampah.

\section{Intervensi Penyelesaian Masalah Mitra}

Kegiatan intervensi penyelesaian masalah edukasi pengelolaan sampah dengan sistem bank sampah ini dilakukan dalam 3 tahapan yaitu: (1) edukasi, (2) pelatihan, dan (3) pendampingan. Kegiatan edukasi tentang pengelolaan sampah dengan sistem bank sampah yang meliputi: (1) konsep pengelolaan sampah domestik, dan (2) manajemen bank sampah dalam meningkatkan nilai ekonomi sampah domestik, disampaikan oleh Dewa Ngakan Gde Wahyu Mahatma Putra, S.ST., M.ARS. Sebelum kegiatan edukasi dimulai, peserta diberikan lembar pre-test sebanyak 10 soal untuk diisi sebagai gambaran awal pengetahuan peserta tentang pengelolaan sampah dengan sistem bank sampah. Setelah kegiatan pengisian lembar pretest selesai, selanjutnya dilakukan kegiatan pemaparan materi (Gambar 1). Selain disajikan dalam bentuk power point, materi juga disajikan dalam bentuk modul yang diberikan kepada peserta dalam bentuk soft file (Gambar 2a). Materi edukasi terdiri dari: (1) konsep pengelolaan sampah domestik, dan (2) manajemen bank sampah dalam meningkatkan nilai ekonomi sampah domestik. Metode interaktif dengan diskusi tanya jawab yang dilakukan dalam kegiatan edukasi ini meningkatkan antusiasme peserta dalam mengikuti materi edukasi yang disampaikan. Hal ini dibuktikan dengan adanya 3 pertanyaan yang disampaikan oleh peserta selama proses edukasi yaitu: (1) Bagaimana cara membiasakan diri untuk tidak buang sampah sembarangan?; (2) Apakah sampah diolah secara dibakar itu dapat mencemari lingkungan?; dan (3) Bagaimana caranya mengolah sampah popok bayi?.

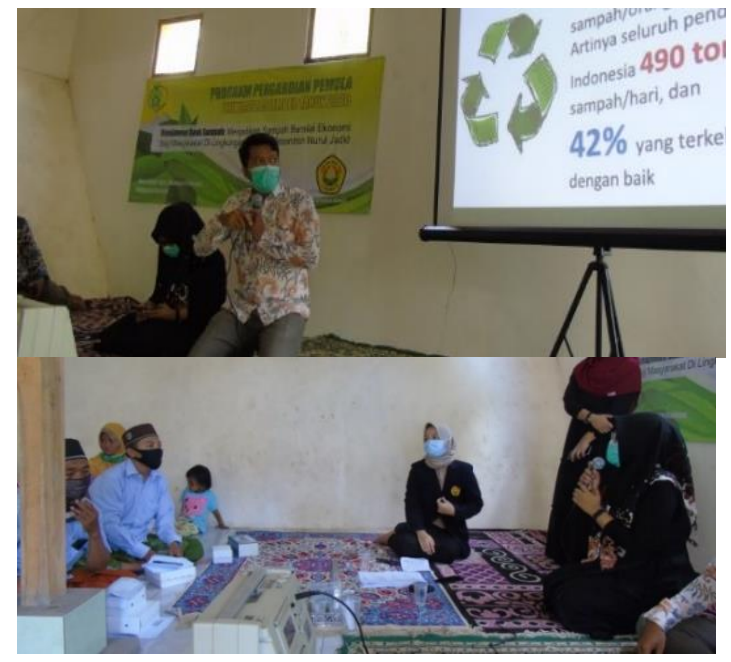

(a)

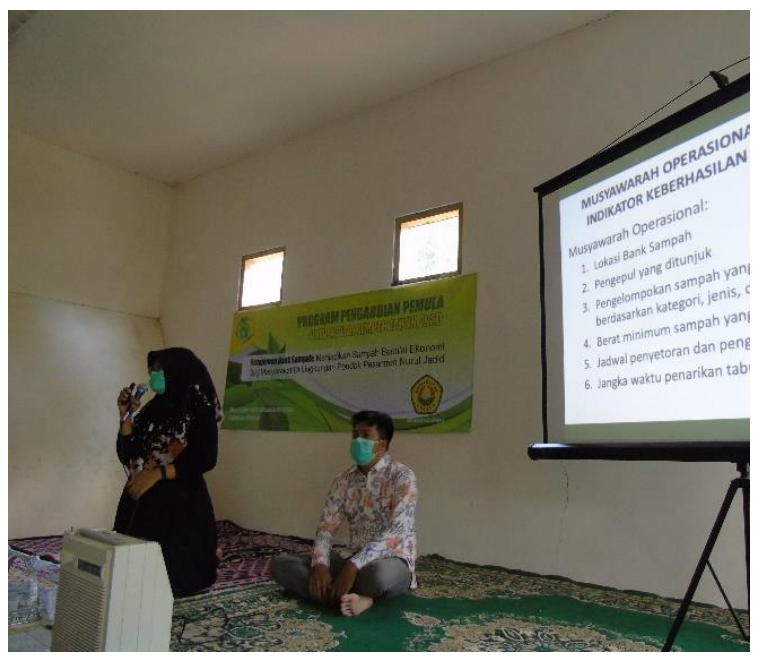

(b)

Gambar 1. (a) Edukasi Pengelolaan Sampah dengan Sistem Bank Sampah. (b) Pelatihan Penerapan Sistem Bank Sampah

Seluruh pertanyaan tersebut dijawab langsung oleh narasumber dan untuk melengkapi jawaban tersebut, narasumber memberikan kesempatan kepada peserta untuk memberikan feedback sehingga mendapatkan jawaban yang diharapkan. Bagian akhir dari kegiatan edukasi ini penyampaian kesimpulan dari materi serta penekanan pada para peserta tentang pentingnya pengelolaan sampah rumah tangga mulai dari sumber dan implementasi bank sampah menjadikan sampah bernilai ekonomi yang dapat menguntungkan masyarakat.

Setelah kegiatan edukasi selesai, peserta diberikan lembar post-test untuk mengukur peningkatan pengetahuan peserta tentang pengelolaan sampah dengan sistem bank sampah. Pengisian lembar pre-test dan post-test ini dilakukan oleh 32 peserta saja karena 3 peserta tidak bersedia mengisi lembar pre-test dan post-test. Hasil analisis statistik dari nilai lembar pre-test dan post-test peserta menunjukkan bahwa terdapat perbedaan antara hasil pre-test dan post-test peserta ( $\mathrm{p}$-value $=0,046$ ) yaitu terdapat peningkatan nilai sebesar 10,938 poin. Hal ini menujukkan bahwa kegiatan edukasi yang dilakukan dalam kegiatan pengabdian kepada masyarakat ini efektif dalam meningkatkan pengetahuan peserta tentang pengelolaan sampah dengan sistem bank sampah. 


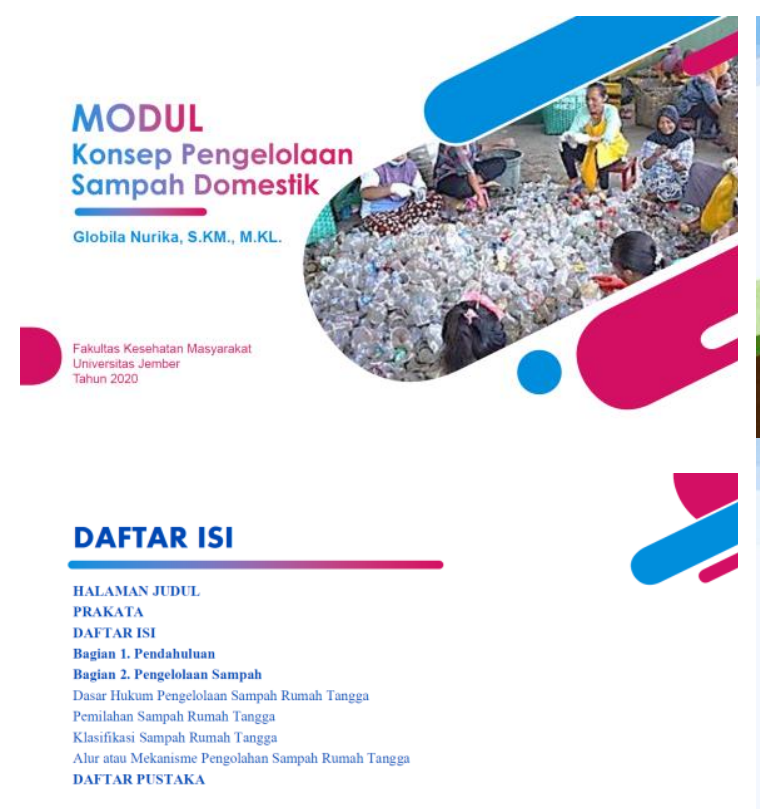

(a)

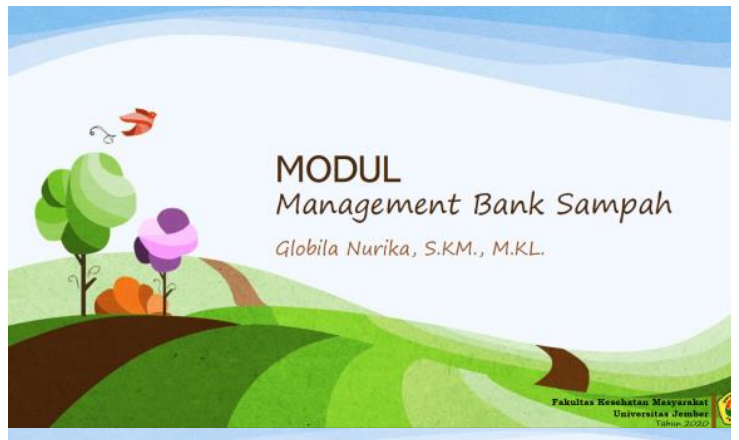

DAFTAR ISI

I нацамиллd II PRIKITA III DAFTAR IS 01 Bagian 1. Mengenal Bank Sampas 02 Pengertian Bank Samp 03 Manfant Bank Sampalh 04 Bagian 2. Pendiritan dan Pengembangen os Standarisasi Sistem Bank Sampat 06 Mekanisme Sistem Bank Sumpe 07 Keuntungan Sistem Bank Samper o8 Musyawarnh Dun Pembernukan Pengunus Bank Samp 09 Musgawarah Operasional, Target, D 15 DAFTAR PTSTAKA
C

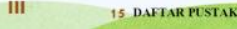

(b)

Gambar 2. (a) Modul "Konsep Pengelolaan Sampah Domestik". (b) Modul "Manajemen Bank Sampah"

Kegiatan pelatihan penerapan sistem bank sampah dilakukan dengan menggunakan media power point dan pemutaran video. Fasilitator dalam pelatihan ini adalah Globila Nurika, S.KM., M.KL. Pada awal pelatihan disampaikan materi pengantar tentang sistem bank sampah yang selanjutnya dilakukan role play. Materi pelatihan juga disediakan dalam bentuk soft file modul yang dapat diakses oleh peserta pasca kegiatan pengabdian kepada masyarakat (Gambar 2b). Peserta ditunjuk untuk menjadi nasabah yang akan melakukan pemilahan sampah dan penyetoran sampah ke bank sampah, petugas divisi administrasi, petugas divisi administrasi, petugas divisi pencatatan, petugas divisi penimbangan, petugas divisi pengepakan, dan petugas pengepul sampah yang masing-masing terdiri dari 1 orang peserta sehingga terdapat 7 orang peserta yang akan melakukan role play manajemen bank sampah. Kegiatan pelatihan dengan metode role play ini diikuti secara antusias oleh peserta. Hal ini dibuktikan dengan adanya beberapa pertanyaan yang diajukan oleh peserta setelah kegiatan role play selesai dilakukan. Adapun pertanyaan yang disampaikan oleh peserta yaitu: (1) Apakah pecahan kaca dapat dikumpulkan dalam bank sampah?; (2) Berapa banyak kapasitas sampah yang harus dikumpulkan untuk dapat di jual ke pengepul Induk?; dan (3) Bagaimana caranya agar masyarakat mau menabungkan sampahnya?.

Seluruh pertanyaan tersebut ditanggapi langsung oleh narasumber dan untuk melengkapi jawaban tersebut, narasumber memberikan kesempatan kepada peserta untuk memberikan feedback sehingga mendapatkan jawaban yang diharapkan. Hasil observasi kegiatan pelatihan ini menunjukkan bahwa peserta telah mampu melakukan kegiatan manajemen bank sampah dan menjalankan peran secara baik sebagai nasabah, petugas divisi administrasi, petugas divisi administrasi, petugas divisi pencatatan, petugas divisi penimbangan, petugas divisi pengepakan, dan petugas pengepul sampah.

Setelah kegiatan edukasi dan pelatihan selesai, kegiatan pengabdian kepada masyarakat selanjutnya dilakukan diskusi bersama pengelola Pondok Pesantren yang diwakili oleh 5 orang. Kegiatan ini bertujuan untuk pendampingan bagi pengelola Pondok Pesantren untuk membentuk sistem manajemen Bank Sampah di Pondok Pesantren Nurul Jadid. Kegiatan diskusi dipimpin oleh Hj. Nurul Qomariyah. Diskusi ini menghasilkan beberapa kesepakatan bersama dalam pembentukan sistem manajemen bank sampah di Pondok Pesantren Nurul Jadid meliputi: (1) susunan organisasi bank sampah (Gambar 3), dan (2) alur manajemen bank sampah (Gamabar 4). Selain itu, pengepul sampah yang ditunjuk untuk mengumpulkan sampah yang telah dikumpulkan oleh bank sampah Pondok Pesantren Nurul Jadid adalan Bak Sampah Induk Forum Kabupaten Sehat (FKS) Kabupaten Situbondo. Bank Sampah Induk FKS Kabupaten Situbondo ini dipilih karena kemampuannya untuk mengankut sampah dari lokasi bank sampah di Pondok Pesantren Nurul Jadid. Jumlah nilai beli sampah setiap jenis adalah sebesar Rp. 1000,-/kg. Nominal tersebut mengalami penurunan dari sebelumnya dikarenakan pengaruh kondisi pandemi covid-19 sehingga 
penjualan sampah mengalami penurunan. Adapun jenis sampah yang dapat ditabung pada bank sampah ini adalah sampah jenis kardus, botol/gelas plastik, botol orson/kecap, besi, dan kertas HVS

STRUKTUR ORGANISASI

BANK SAMPAH PP. NURUL JADID

Sumberanyar, Mlandingan, KAB. SITUBONDO, Jawa Timur

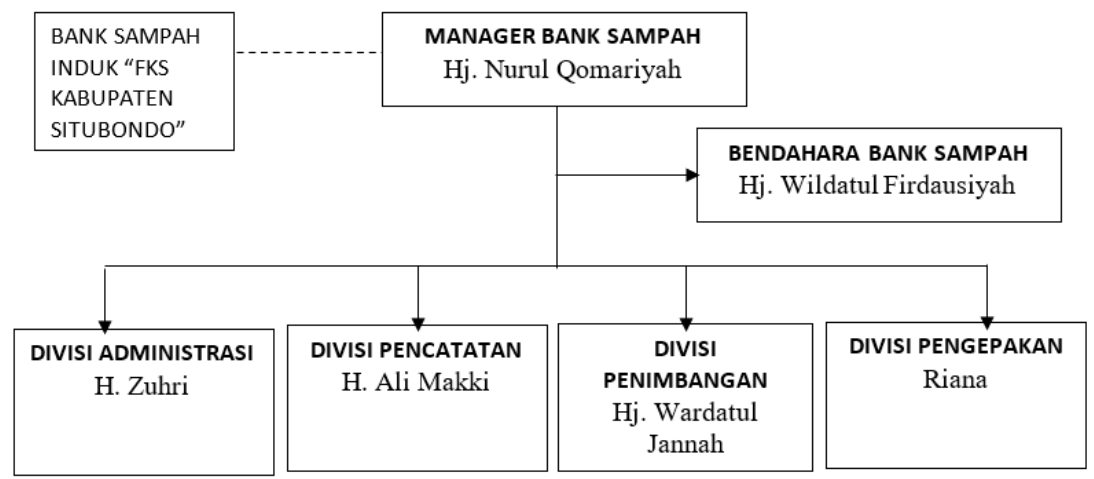

Gambar 3. Struktur Organisasi

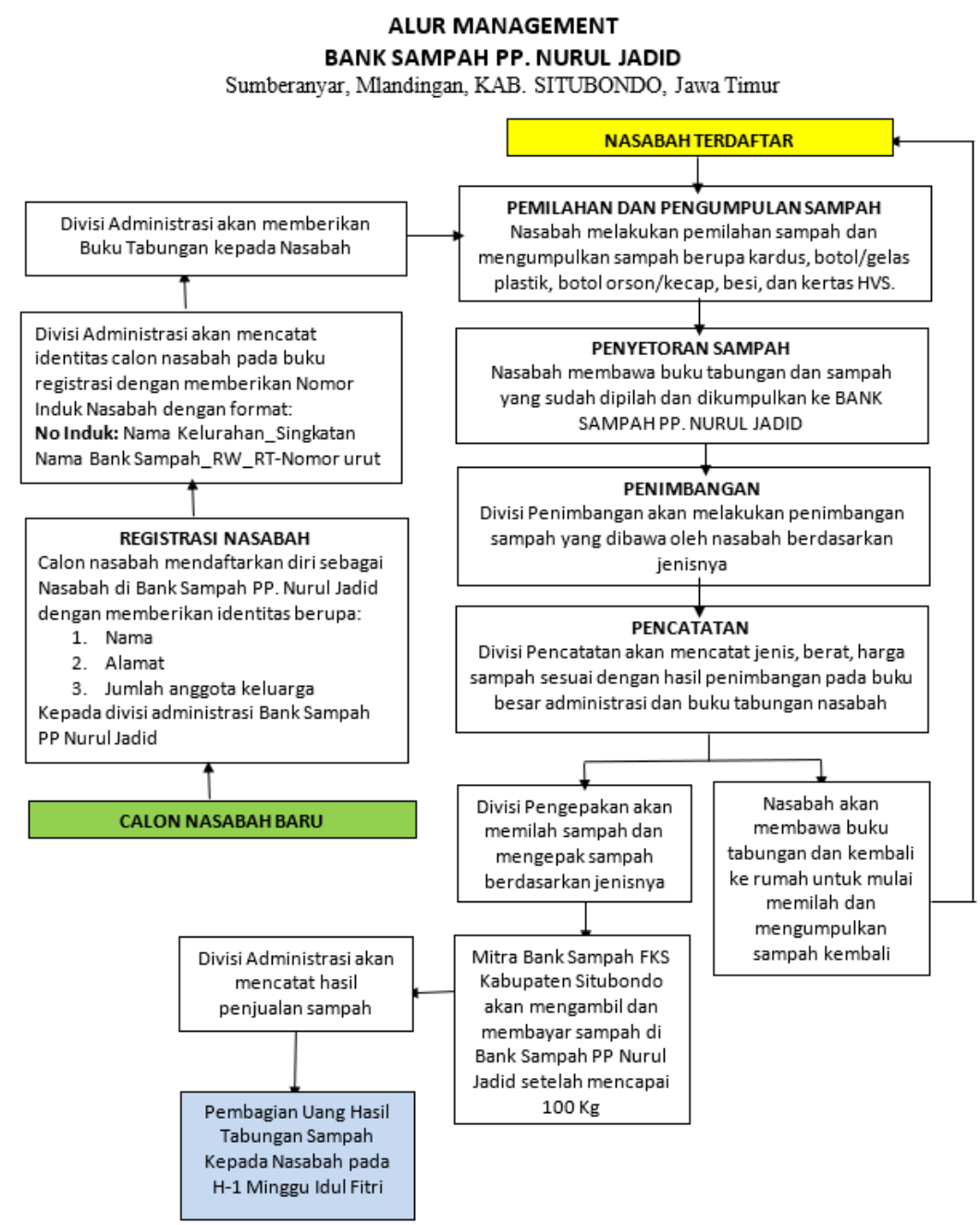

Gambar 4. Alur Management Bank Sampah PP Nurul Jadid

Sebagai bentuk pelaksanaan manajemen bank sampah di Pondok Pesantren Nurul Jadid, maka disusun pula alur manajemen bank sampah yang akan diterapkan. Hal ini bertujuan agar proses pengumpulan hingga penjualan sampah kepada pengepul induk dapat berjalan dengan lancar. Alur manajemen tersebut disajikan dalam diagram alir pada Gambar 4. 


\section{Evaluasi Kegiatan Pengabdian Kepada Masyarakat}

Hasil evaluasi dari kegiatan pengabdian kepada masyarakat ini dibagi menjadi tiga bagian yaitu: (1) evaluasi pelaksanaan edukasi, (2) evaluasi pelaksanaan pelatihan, dan (3) evaluasi kegiatan pendampingan. Evaluasi pertama terhadap pelaksanaan edukasi menunjukkan adanya peningkatan pengetahuan peserta tentang pengelolaan sampah dengan sistem bank sampah. Hal ini sejalan dengan hasil pengabdian kepada masyarakat yang dilakukan oleh Yuhandini, dkk (2021) yang menujukkan bahwa kegiatan edukasi mampu untuk meningkatkan pengetahuan sasaran kegiatan. Kegiatan edukasi dengan metode interaktif dengan diskusi dua arah memberikan peluang yang besar bagi peserta untuk melakukan konfirmasi terhadap informasi yang didapatkan sehingga mencapai pemahaman terhadap suatu materi yang maksimal. Evaluasi kedua terhadap pelaksanaan pelatihan menunjukkan adanya peningkatan kemampuan peserta dalam melakukan kegiatan manajemen bank sampah. Melalui metode role play, peserta dapat mengamati tingkah laku yang diperankan oleh pemain dan kemudian mempraktekkan tingkah laku tersebut bersama peserta lainnya. Hal ini sejalan dengan hasil kegiatan yang dilakukan oleh Dharmayanti (2013) yang menunjukkan bahwa intervensi pelatihan teknik role playing dapat meningkatkan keterampilan komunikasi interpersonal sasaran kegiatan.

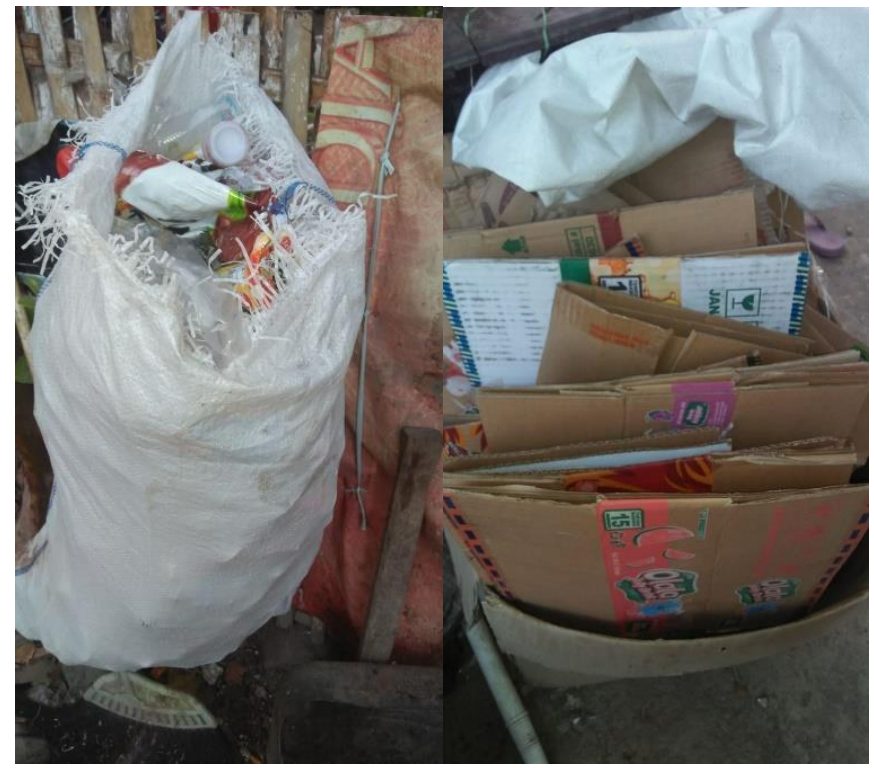

Gambar 5. Jenis Sampah yang Dikumpulkan pada Bank Sampah Pondok Pesantren Nurul Jadid

Evaluasi terakhir adalah terhadap kegiatan pendampingan pembentukan sistem bank sampah yang menunjukkan bahwa pengelola Pondok Pesantren Nurul Jadid telah mampu menyusun sistem organisasi bank sampah (Gambar 3) dan alur manajemen bank sampah (Gambar 4) dengan baik. Selanjutnya, kegiatan komunikasi dengan pihak pengelola Pondok Pesantren pasca kegiatan pengabdian masyarakat selesai untuk mengetahui implementasi bank sampah yang telah dibentuk juga dilakukan. Hasil komunikasi lanjutan pasca kegiatan pengabdian kepada masyarakat ini yaitu sistem bank sampah sudah berjalan dan proses pengumpulan sampah yang dilakukan mayoritas berjenis kardus dan botol bekas (Gambar 5). Kegiatan pemilahan sampah dari sumber terus dilakukan hingga dikumpulkan ke lokasi bank sampah yang ditentukan yaitu di Pondok Pesantren Nurul Jadid.

\section{PENUTUP}

\section{Simpulan}

Hasil kegiatan pengabdian kepada masyarakat yang dilakukan di Pondok Pesantren Nurul Jadid menunjukkan bahwa kegiatan ini merupakan suatu upaya yang sangat strategis dalam rangka menyiapkan peserta untuk beraktivitas melakukan pengelolaan sampah mulai dari sumbernya dan membuat sampah memiliki nilai ekonomi. Kegiatan ini telah mendapatkan respon yang sangat positif dari berbagai pihak, diantaranya dari peserta dan pengelola Pondok Pesantren. Kendala yang dihadapi dalam pelaksanaan kegiatan pengabdian kepada masyarakat ini adalah waktu pelaksanaan kegiatan edukasi yang relative singkat untuk meningkatkan pengetahuan dan keterampilan peserta tentang pengelolaan sampah dengan menggunakan system bank sampah. Akan tetapi hal tersebut dapat teratasi dengan penggunaan media audiovisual serta penerapat beberapa metode penyampaian semenarik mungkin untuk meningkatkan antusiasme peserta dalam menyimak materi yang disampaikan. Hal ini dibuktikan dengan adanya 
peningkatan pengetahuan dan keterampilan peserta dalam melakukan pengelolaan sampah dengan menggunakan system bank sampah, serta telah terbentuknya system bank sampah yang sudah berjalan sesuai alur yang telah dibuat.

\section{Saran}

Saran untuk keberlanjutan sistem bank sampah yang teah terbentuk adalah pihak pengelola Pondok Pesantren terus memotivasi masyarakat di lingkungan Pondok Pesantren untuk terus memilah sampah mulai dari sumber dan mengumpulkannya ke bank sampah. Selain itu dibentuk inovasi lanjutan program bank sampah, misalnya hasil tabungan dapat dikonversi menjadi sembako dan beberapa inovasi lainnya untuk memotivasi masyarakat untuk menabung sampah.

\section{Ucapan Terima Kasih}

Ucapan terima kasih tim penulis sampaikan kepada Lembaga Penelitian dan Pengabdian Kepada Masyarakat Universitas Jember atas pendanaan kegiatan pengabdian kepada masyarakat ini. Selain itu, ucapan terima kasih juga disampaikan kepada pengelola Pondok Pesantren, perwakilan santriwan dan santriwati, serta perwakilan masyarakat di lingkungan Pondok Pesantren Nurul Jadid yang telah meluangkan waktu dan antusias dalam mengikuti pelaksanaan pengabdian kepada masyarakat ini.

\section{E. DAFTAR PUSTAKA}

Dharmayanti, Putri Ari. (2013). Teknik Role Playing Dalam Meningkatkan Keterampilan Komunikasi Interpersonal Siswa SMK. Jurnal Pendidikan dan Pengajaran. Vol 46(3): 256-265. https://ejournal.undiksha.ac.id/index.php/JPP/article/viewFile/4228/3299

Ibrahim, R (2016) Pesantren dan Pengabdian Masyarakat: Studi Kasus Pondok Pesantren DawarBoyolali Jawa Tengah. Al-Tahrir, Vol. 16, No. 1 Mei $2016: 89$ - 108

Kompas. (2020). Indonesia Hasilkan 64 Juta Ton Sampah, Bisakah Kapasitas Pengelolaan Tercaai Tahun 2025?. https://www.kompas.com/sains/read/2020/12/18/070200023/indonesia-hasilkan-64-jutaton-sampah-bisakah-kapasitas-

pengelolaan?page=all\#: :text=Data\%20Kementerian\%20Lingkungan\%20Hidup\%20dan,ton\%20ti mbunan\%20sampah\%20setiap\%20tahunnya. Diakses tanggal 16 Februari 2022

Peraturan Pemerintah Republik Indonesia Nomor 81 Tahun 2012 Tentang Pengelolaan Sampah Rumah Tangga Dan Sampah Sejenis Sampah Rumah Tangga

Setiawan, Anton. (2021). Membenahi Tata Kelola Sampah Nasional. https://indonesia.go.id/kategori/indonesia-dalam-angka/2533/membenahi-tata-kelola-sampahnasional, diakses tanggal 16 Februari 2022.

SIPSN. (2020). Kinerja Pengelolaan Sampah. SIPSN. Thtps://sipsn.menlhk.go.id/sipsn/. Diakses tanggal 13 September 2021

Yuhandini, DS., Santi Wahyuni, Neli Nurlina. (2021). Efektifitas Edukasi Kader Kesehatanterhadap Peningkatan Pengetahuan Dan Kemampuan Mendeteksi Dini Tanda Bahaya Pada Kehamilan Dan Nifas Tahun 2016. Jurnal Ilmiah Pannmed (Pharmacyst, Analyst, Nurse, Nutrition, Midwivery, Environment, Dental Hygiene. Vol 16 (1): 58-64. DOI: https://doi.org/10.36911/pannmed.v16i1.994 